\title{
Diversity of phytopathogenic fungi on soybean seed in Serbia
}

\author{
Slobodan Krsmanović* · Kristina Petrović · Marina Ćeran · Vuk Đorđević . \\ Predrag Ranđelović · Simona Jaćimović · Zlatica Miladinov
}

Institute of Field and Vegetable Crops, 30 Maksima Gorkog, 21000 Novi Sad, Serbia

\begin{abstract}
Summary: Soybean is one of the most important industrial crops in the world. The rich nutritional content of the seed is the reason for the increased cultivation of this crop all over the world. However, a large number of phytopathogenic fungi that exist in soybean seeds can reduce the nutritional content, germination, and seed vigor. Soybean seed samples were collected from experimental fields in seven locations in Vojvodina Province, Serbia in the period 2016-2018. From each sample, 100 seeds were randomly selected. Seeds were surface-disinfested in $4 \%$ sodium hypochlorite for $5 \mathrm{~min}$, washed two times in sterile water, and dried on a filter paper. All 100 seeds were placed in 20 Petri dishes with standard potato dextrose agar medium (PDA), five seeds in each, and incubated at $22 \pm 2^{\circ} \mathrm{C}$ for seven days, under $12 \mathrm{~h}$ of alternating light/dark conditions. The first assessment was performed on the fourth day after isolation. The health status analysis of soybean seed showed that Peronospora manshurica, Macrophomina phaseolina, Botrytis cinerea, Cerrospora kikucbii as well as the species from genera Alternaria, Diaporthe, and Fusarium had colonized soybean seed in Serbia over three years. Species from the genus Alternaria and Peronospora manshurica were dominant in all three examined years. Furthermore, it has been noticed that weather conditions, location, and cultivar significantly influenced the intensity of the infection. The results of this study have shown which pathogens pose a threat to successful soybean seed production and help in finding preventive measures to control these pathogens during vegetation.
\end{abstract}

Key words: soybean, seed, phytopathogenic fungi, incidence of infection

\section{Introduction}

Soybean (Glycine max (L.) Merr.) is the most commonly cultivated protein-oil crop in the world, and in Serbia as well, primarily because of the seed which is one of the major food and feed sources (Vlahovic et al., 2013). Thus, the production of high-quality soybean seed is very important, which can be improved by appropriate agronomic measures such as sowing certified, disease-free seed. To keep the high health status of the seed, it is necessary to apply crop rotation which helps to break the disease cycle in the field and

Corresponding author:

slobodan.krsmanovic@ifvcns.ns.ac.rs

Acknowledgements:

The research was supported by the Ministry of Education, Science and Technological Development of the Republic of Serbia, grant number: 451-0368/2020-14/200032

Cite this article:

Krsmanović S., Petrović K., Ceran M., Đorđević V., Ranđelović P., Jaćimović $S$., Miladinov Z. (2020). Diversity of phytopathogenic fungi on soybean seed in Serbia. Ratar. Fourt, 57 (3), 80-86. thus increase yield. Crop rotation of soybean and crops that share common diseases such as sunflower, as well as cultivation in monoculture, results in increased inoculum source and the seed infection frequency by pathogens (Vidić et al., 2006).

More than 200 phytopathogenic microorganisms (primarily fungi) have been detected on soybean (Hartman et al., 2015), and it is considered that about 30 species can cause significant economic damage (Roy et al., 2000). Most of them colonize soybean seed and thus spread and distribute in other soybean-growing regions worldwide (Backman et al., 1985; Pioli et al., 1999; Vidić et al., 2006). The most common fungi of soybean seed worldwide are species from following genera: Diaporthe, Fusarium, and Alternaria as well as species: Cercospora kikuchï, Rbiroctonia solani Kühn, Sclerotinia sclemtionum, Botrytis cinerea Persoon, Macropbomina pbaseolina, and Peronospora manshurica (Wrather et al., 2010; Tenuta et al., 2015).

Phytopathogenic fungi, such as species of the genus Diaporthe, negatively affect germination and seed quality (Petrovic et al., 2015; 2016; 2018). Seed infections can be with no visible symptoms (latent infection) or with 
typical symptoms such as rot, mycelia, or discoloration. In the U.S. during the period from 2006 to 2009 , seedling diseases were on the second place of importance as a causative factor in reducing the soybean yield (Koenning \& Wrather, 2010). In the top eight soybean-producing countries during 2006 , soybean yield was mostly affected by Septoria glycines Hemmi, Cercospora kikuchii (Matsumoto \& Tomoyasu) Gardner, Peronospora manshurica (Naumov) Sydow, Macrophomina phaseolina (Tassi) Goidànich, Sclerotinia sclerotionum (Libert) de Bary, Phakopsora pachyrbiri Sydow \& Sydow and with phytopathogenic fungi from the genus Diaporthe and Fusarium species complex (Wrather et al., 2010). In Serbia, the most prevalent pathogen in soybean seed in the past was $P$. manshurica, followed by species from the following genera: Altemania, Fusarium and Diaporthe (Medić-Pap et al., 2007; Petrović \& Vidić, 2010; Lević et al., 2012). High humidity at the time of maturation and soybean harvest can additionally increase the harmfulness or seed infection degree with phytopathogenic fungi. Soybean yield losses caused by diseases varied due to weather and climatic conditions in most countries. The dry areas are favorable for diseases such as charcoal rot caused by $M$. phaseolina (Wrather \& Koenning, 2006). Wet weather is suitable for developing Sclerotinia stem rot in the U.S. and Canada, Rhiactonia blight in India, and anthracnose in the central and northern portions of Brazil and Paraguay (Wrather et al., 2010). Besides, wet weather at harvest time enhanced Diaporthe seed decay in Canada (Xue et al., 2007).

Since soybean production in Serbia and soybean seed trade in Europe has rapidly increased in the last several years, spread of the seed-borne diseases can be expected. The aim of this study was to make a profile of the phytopathogenic fungi that colonize soybean seed in the main regions of soybean production in Serbia.

\section{Material and Methods}

Isolation and identification of seed phytopathogenic fungi

Soybean seed samples were collected from experimental fields in seven locations in Vojvodina Province, Serbia in the period 2016-2018. Three cultivars from different maturity groups (MG) were examined: 'Galina' (MG=0), 'Sava' (MG=I), and 'Rubin' (MG=II). First, samples of 100 seeds per cultivar were previously studied for the presence of an obligate host-specific pathogen $P$. manshwica using binocular loupe. Afterward, seeds were surface-disinfested in $4 \%$ sodium hypochlorite for $5 \mathrm{~min}$, washed two times in sterile water, and dried on a filter paper. All 100 seeds were placed in 20 Petri dishes with standard potato dextrose agar medium (PDA), five seeds in each, and incubated at $22 \pm 2^{\circ} \mathrm{C}$ for seven days, under $12 \mathrm{~h}$ of alternating light/dark conditions.

Fungi colonies developed from the infected seed and were transferred on fresh PDA medium and incubated in a thermostat at $23 \pm 2^{\circ} \mathrm{C}$. The fungal pathogens of the soybean seed were profiled using morphological and cultural features. The first assessment was performed on the fourth day after isolation by observation of macro- and microscopic morphological features of mycelium and sporulation structures that were formed. Some of the colonies were left more days for incubation until identified. Pathogen identification was performed using naked-eye detection of cultural and macro morphological characteristics of phytopathogenic fungi, such as colony appearance, the color of mycelium, and asexual and sexual structures, if the fungi have formed them. Afterwards, the morphological features such as the type of conidia, their length and shape were studied in detail under a light microscope at different magnifications $(\times 10, \times 20$, and $\times 40)$. As a basis for comparing the results of the identification, the Compendium of Soybean Diseases and Pests, fifth edition (Hartman et al., 2015) was used, where all the listed morphological features of the genera and their species found in this study are precisely described.

The incidence of fungal pathogens per sample of soybean seed is presented in percentage, and the results were calculated using the following formula:

\section{Number of the infected seeds by fungal} 100

species or genus $x \frac{100}{\text { Total number of seeds in a sample }}$

\section{Results and discussion}

Data obtained from three consecutive years have shown differences in the incidence of phytopathogenic fungi on the soybean seeds compared to year, location, and cultivars (Figs. 1, 2, and 3).

The lowest fungal incidence of seed was noticed in 2017. The reason might be the absence of precipitation at the time of pod and seed development as well as plant maturity stage, which does not favor the development of the phytopathogenic population on seed (Petrović \& Vidić, 2010). During 2017, the highest amount of precipitation was observed in Sabac location (Fig 4), where also the highest seed infection was recorded on cvs. 'Sava' (26\%) and 'Galina' (9\%) followed by $1 \%$ of seed infection of crs. 'Galina' and 'Rubin' in location Karavukovo.

In 2016 and 2018, climatic conditions were favorable for pathogen development, and the presence

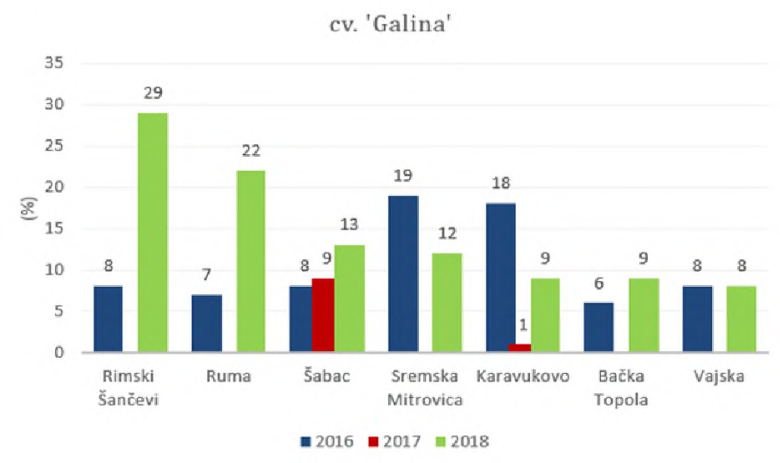

Figure 1. The incidence of fungal pathogens on the soybean seed of cv. 'Galina' (\%) 


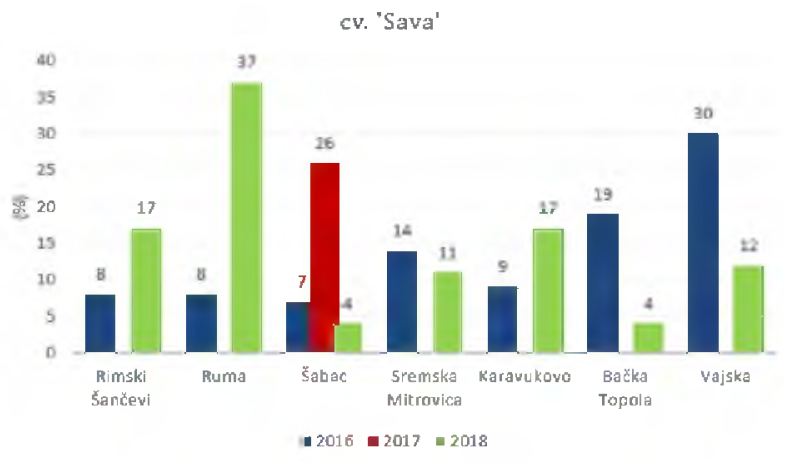

Figure 2. The incidence of fungal pathogens on the soybean seed of cr. 'Sava' (\%)

of phytopathogenic fungi on soybean seeds was confirmed on all locations and cultivars. The percentage of seed infection ranged from $4 \%$ to $37 \%$. The highest percentage of seed infection of all three cultivars in 2016 was recorded in locations Vajska, Backa Topola, Sremska Mitrovica, and Karavukovo. In Vajska and Bačka Topola, seed infection of $30 \%$ and $22 \%$ were detected on a seed of 'Sava' and 'Rubin', respectively, followed by locations Sremska Mitrovica (19\%) and Karavukovo (18\%) on soybean seed of 'Galina'.

The highest percentage of seed infection of all three cultivars was recorded in locations Ruma and Rimski Sančevi. In Ruma, seed infection of $37 \%$ was detected on 'Sava' in 2018 followed by $23 \%$ of 'Rubin' and $22 \%$ of Galina. Also, higher seed infection was recorded at location Rimski Sančevi on the seed of 'Galina' $29 \%$ in 2018 , followed by $19 \%$ and $17 \%$ of seed infection of 'Rubin' and 'Sava', respectively, in the same year.

From the above data, it can be concluded that precipitation and high humidity during the period of soybean maturity in 2017 led to a high percentage of seed infection with phytopathogenic fungi in Sabac location. But in 2016 and 2018, there was no connection between the amount of precipitation during pod formation and the soybean maturation period. Distribution of precipitation and maintenance of constant humidity in the freld during soybean

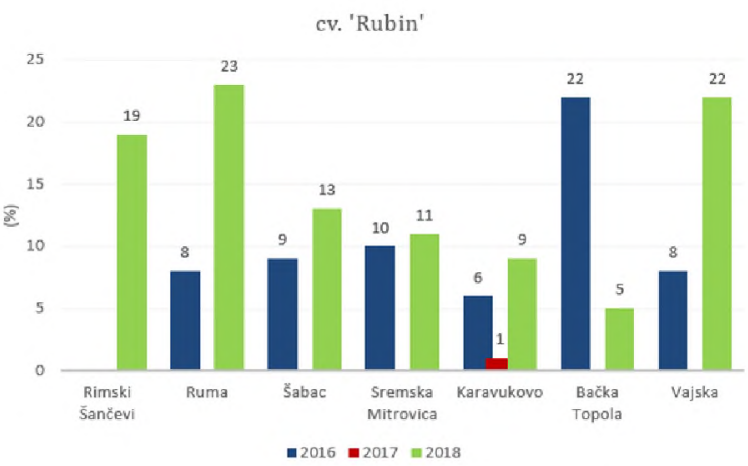

Figure 3. The incidence of fungal pathogens on the soybean seed of cv. 'Rubin' (\%)

maturation is a far more important characteristic for observation than the total amount of precipitation in the same period. Due to the lack of data on precipitation distribution, only the total amount of precipitation during soybean maturation is shown, so that may be the reason for the lack of connection. Moreover, the connection between these two factors is opposite compared to 2017 and probably depends on the interaction of different factors. One of those factors is the choice of cultivar, and the best example is 2016 and the location of Vajska. Although it was the locality

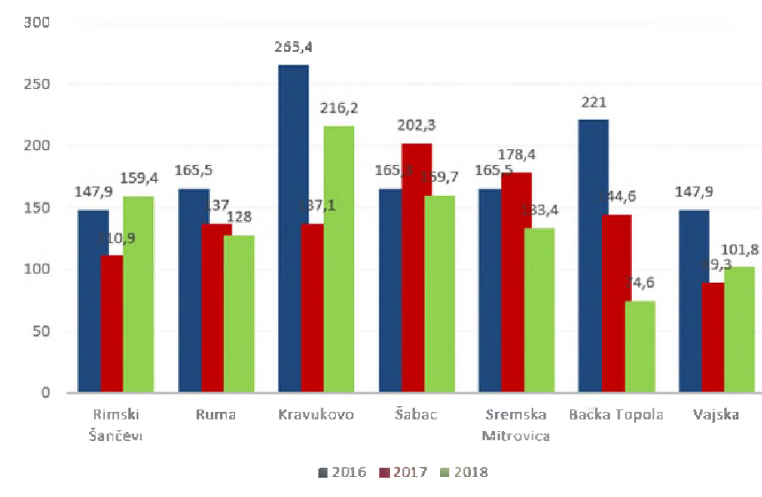

Figure 4 . The sum of precipitation in the period of soybean maturation, July-September (2016-2018)
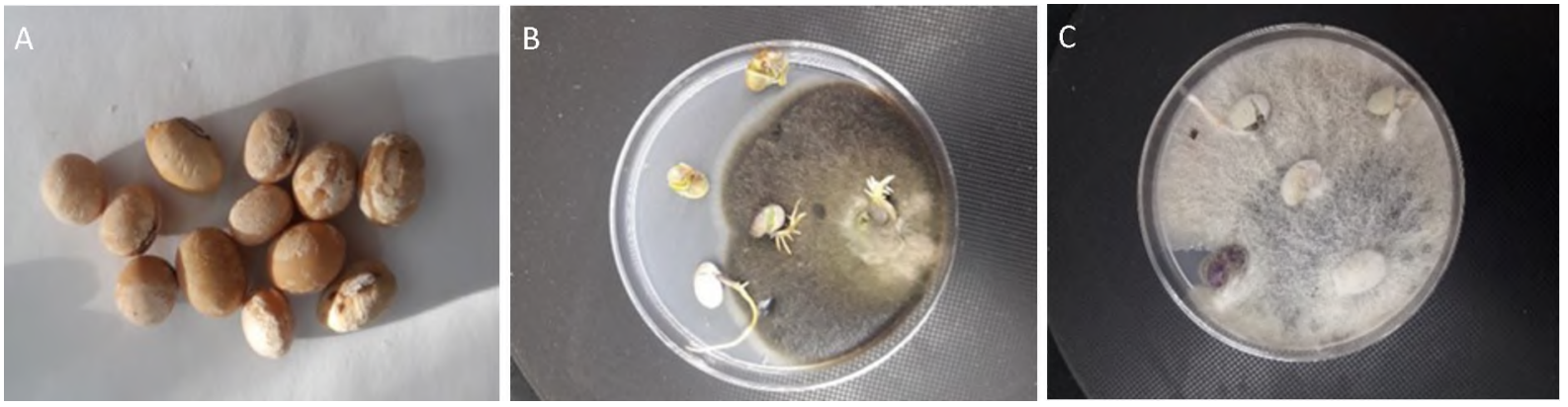

Figure 5. Infected seeds, A: P. manshurica on soybean seed, B-C: latently infected seed by Alternaria spp. and Diaporthe spp., respectively 
with the lowest rainfall in 2016, the highest level of infection was found on soybean seed of 'Sava' (30\%) with $M G=I$, while on the other two cultivars 'Galina' (MG=0; early cultivar) and 'Rubin' (MG=II; late cultivar), the percentage of infection was lower $(8 \%)$. This can be explained by favorable interaction between factors for the development of the phytopathogenic fungi on the seed during the maturity of 'Sava' in Vajska.

Examination of the fungal population structure on soybean seed (Fig. 5) revealed the presence of species from following genera: Alternaria $(28.9 \%)$, Fusarium $(10.3 \%)$, and Diaporthe $(8.8 \%)$, as well as the species: $P$. manshunica (44\%), B. cinerea $(6.6 \%), M$. phaseolina $(0.7 \%)$ and C. kikuchii $(0.7 \%)$ (Fig. 6A). The population structure and the infection incidence mostly depended on the climatic conditions in the examined years.

Peronospora manshurica and species from the genus Alternaria had the highest percentage of prevalence in all examined years. The most common species from the genus Alternaria that colonize soybean seed are $A$. alternata (Fries) Keissler and $A$. tenuissima (Nees) Wiltshire (Sinclair \& Backman 1989; Baird et al., 2001). During 2008 and 2009, it was found that $A$. tenuissima was the most dominant species recovered from soybean plants and seed (Jasnić et al., 2011). On the other hand, P. manshurica is an obligate parasite that cannot be isolated on nutritive media. It often occurs on leaves in the field and seed. Systematically infected plants grow from the infected seed and present the main source of infection in the field. There are opposite opinions about the harmfulness of $P$. manshurica. Some authors claim that the disease is not economically harmful while others state it is, especially if the first part of the growing period has abundant rainfall, followed by a long period of drought (Vidić, 1992). Most soybean cultivars that were grown frequently in Serbia had adequate resistance to $P$. manshurica, which was lost over time due to a change in the composition of the parasite (Miladinović et al., 2011).

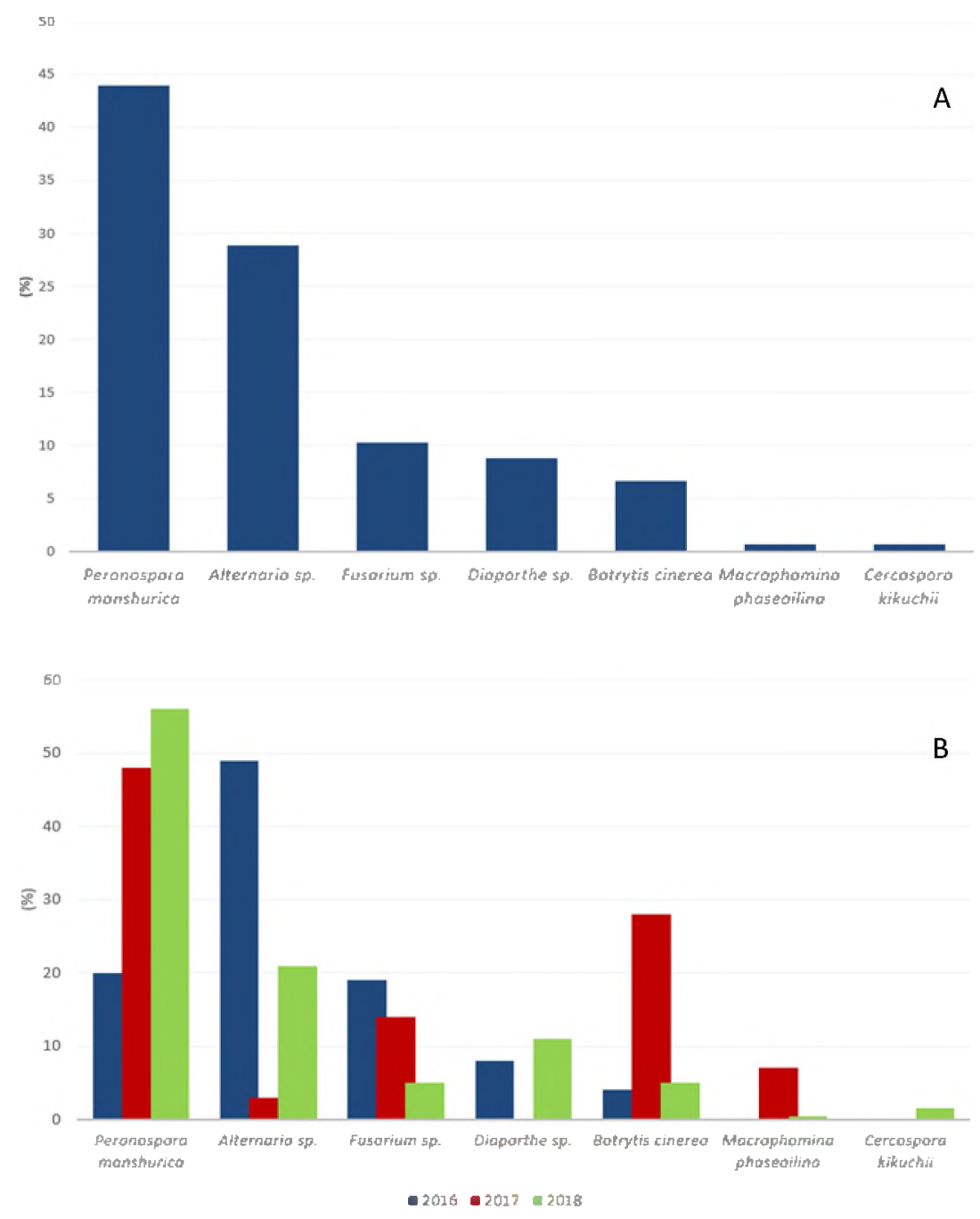

Figure 6. Fungal population on soybean seed, A) in total; B) per years (2016-2018) 
A higher percentage of species from the genus Diaporthe $(11 \%)$ was recorded on soybean seed in 2018. Diaporthe species are economically important pathogens of soybean seed which cause seed decay. $D$. Longicolla (Hobbs) Santos, Vrandečić \& Phillips is the most dominant and the most aggressive pathogen of this complex (Petrovic et al., 2018). This was confirmed by results in the current study. For example, out of the total $12 \%$ infected seed of 'Sava' in locations Vajska, $10 \%$ were colonized by species of Diaporthe complex, where $D$. Longicolla was dominant $(90 \%)$. In recent years, seven species of Diaporthe on soybean seed have been reported in Serbia (Petrović et al. 2015; 2016; 2018), while in this study only three were identified using morphological and cultural features: $D$. longicolla, $D$. caulivora (Athow \& Caldwell) Santos, Vrandečić \& Phillips and D. sojae Lehman. The highest percentage of seed infection in all investigated years was caused by $D$. longicolla $(86 \%)$ followed by $D$. caulivora $(11 \%)$ and $D$. sojae (3\%) (Fig. 7 ).

This study found that soybean seeds in Serbia were colonized in the past three years with $P$. manshunica, $M$. phaseolina, B. cinerea, and C. kikuchii as well as species from genera Alternaria, Diaporthe, and Fusarium. It has also been established that climatic conditions during the growing season, especially during pod and seed development as well as plant maturity stage, strongly affect the fungal population structure on the soybean seed and thus influence the damage caused by pathogenic species. Results show that $P$. manshwica was the prevalent species in 2017 with $48.3 \%$ and 2018 with $56.5 \%$, and species from the genus Alternaria were dominant species of soybean seed in 2016 with $49.2 \%$ percentage of the seed infection. It is known that continuous high humidity throughout the year, as well as higher amounts of precipitation and elevated temperatures at the time of soybean maturation, favor an infection attack and spreading of the disease (Spilker et al., 1981; Rupe \& Ferris, 1986; Balducchi \& Mc Gee, 1987; Vidić et al., 2006). Additionally, postponing harvest after technological maturity due to precipitation progressively increases the percentage of rot and latently infected seed (Vidic et al., 2002). The above facts can explain the difference between the presence of certain phytopathogenic species to the year and location. However, in different parts of the world, precisely because of climatic conditions, the structure of the pathogen population on soybean seed is different. Namely, the main fungal pathogens of soybean seed in the U.S. are the species from the genera Diaporthe and Cerospora (Talenko, 2018), which appeared in a very low percentage in Serbia, especially the genus Cercospora. A similar study was conducted in Nigeria (Oladimeji et al., 2016) where the percentage of phytopathogenic fungi occurrence on 15 soybean cultivars was tested and compared. Phytopathogenic species were determined from the following five genera: Aspergillus, Cumularia, Fusarium, Penicillium, and Diaporthe. The study has shown that the percentage of detected species on seed from different cultivars varied, especially the percentage of species from Penicillium and Fusarium genera. Moreover, it was found that the cotyledon was the most affected site of infection in the seed, but an appearance in relation to weather conditions and location was not investigated.

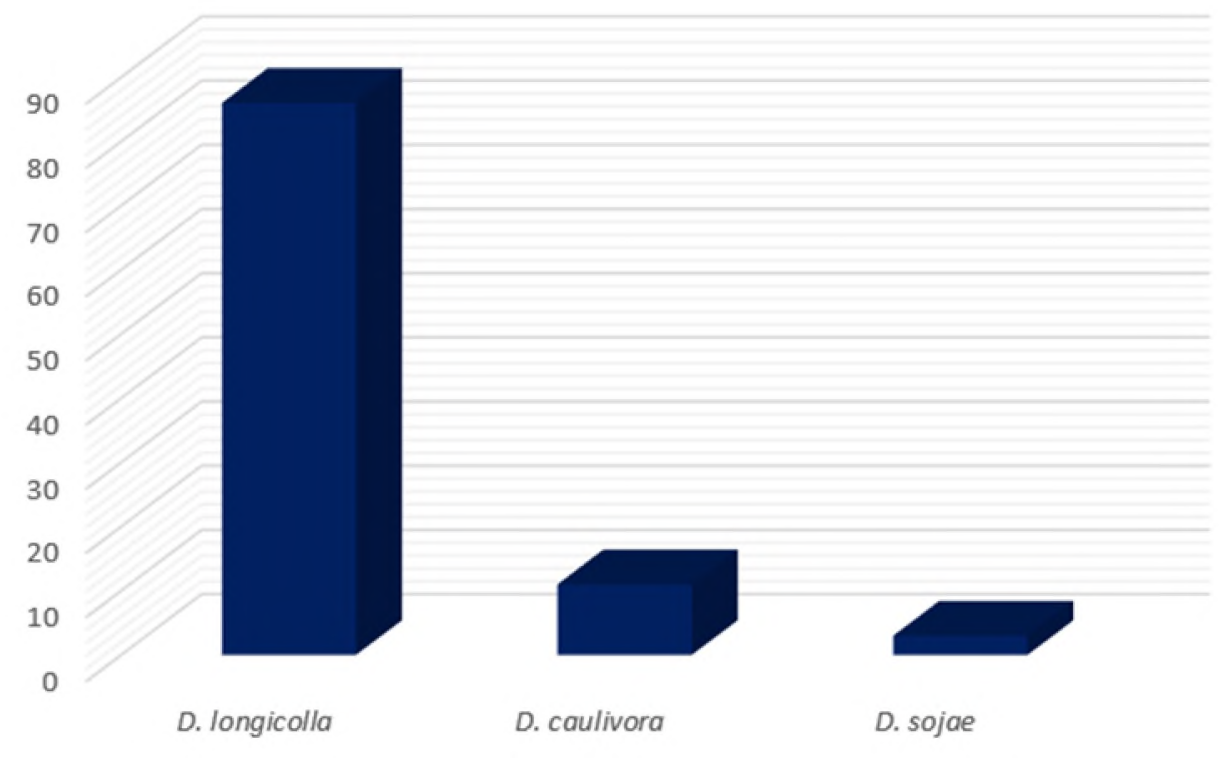

Figure 7. Diaporthe species complex on soybean seeds in the period 2016-2018 
The structure of the pathogen population is also variable in Serbia in different periods. Thus, species from the genera Alternaria and Fusarium are listed as the dominant pathogens on soybean seed in 2008 and 2009 (Petrović \& Vidić, 2010; Lević et al., 2012). The study of Diaporthe species on soybean seed conducted in the period from 2002 to 2004 has shown that the species spectrum of Diaporthe complex varied among years (Vidić et al., 2006). Thus, D. cautivora was dominant in 2002, and D. sojae was prevalent in 2004, while in our study D. Longicolla $(86 \%)$ was the most isolated pathogen in all three examined years. Recent research showed the presence of new species from genus Diaporthe on soybean seed, such as $D$. eres Nitschke, $D$. foeniculina (Saccardo) Udayanga \& Castlebury, D. midis (Fries) Nitschke and D. psendolongicolla Petrovic that were identified as the causative agent of soybean seed decay (Petrovic et al., 2015; 2016; 2018). Although the presence of these species was not identified in this research, there is a possibility that in the future they could become prevalent, which can lead to a negative effect, especially in soybean seed production.

Soybean seed pathogens pose a serious threat to crop establishment causing reduced germination and yield, as well as decreased nutritive content of soybeans seed. It has been found that D. Longicolla and C. kikuchit affect the quality of soybean seed reducing the content of isoflavone, proteins, oil, and fatty acids (Lee et al., 2015). Given that $D$. Longicolla is the dominant species in Serbia, there is a real risk of reducing the qualitative seed content over the years of the excessive occurrence of this pathogen.

\section{Conclusion}

Evaluation of the health status of soybean seed in Serbia in the period from 2016 to 2018 showed that soybean seed was colonized with $P$. manshunica, $M$. phaseolina, B. cinerea, and C. kikuchii, as well as species from genera Alternaria, Diaporthe, and Fusarium. The structure of the fungal population that exists in soybean seed depends on the sum of various factors such as weather conditions, amount of precipitation, precipitation schedule, location, variety selection, inoculum amounts, as well as the interactions of these factors. This was confirmed in the current study, considering that the highest seed infections detected in humid years (2016 and 2018), while seed infection was significantly lower in 2017 due to drought. The most dominant pathogens in all examined years were $P$. manshurica and species from the genus Alternaria. Moreover, species of Diaporthe complex were detected and the most frequent was $D$. Longicolla. Having in mind that this species can severely reduce the nutritional content of soybean seed, there is a real risk of decreasing qualitative seed traits due to the presence of this pathogen in the future. This paper gives a clear picture of pathogen population structure on soybean seed, which helps in defining preventive measures in controlling phytopathogenic species as well as finding solutions for their successful suppression during vegetation, especially in seed production.

\section{References}

Backman, P. A, Weaver, D. B. \& Morgan- Jones, G. (1985): Soybean stem canker: An emerging disease problem. Plant Disease, 69: 641647.

Baird, R. E., Abney, T. S. \& Mullinix, B. G., (2001): Fungi associated with pods and seeds during the $R 6$ and $R 8$ stages of four soybean cultivars in southwestern Indiana. Phytoprotection, 82: 1-11.

Balduchi, A. J. \& McGee, D. C. (1987): Enviromental factors influencing infection of soybean seed by Phomopsis and Diaporthe species during seed maturation. Plant Disease, 71: 209-212.

Hartman, G. L., Rupe, J. C., Sikora, E. J., Domier, L. L., Davies, J. A \& Steffey, K. L (2015): Compendium of Soybean Diseases and Pests (5 $5^{\text {th }}$ Edition). The American Phytopathological Society, St. Paul, Minnesota.

Jasnić, S., Marjanović, Ż., Vidić, M., Bagi, F., Budakov, D., Pavlović, S. \& Stojšin V. (2011): Pathogenic, morphological and molecular characteristics of Altemaria temissima from soybean. Zbomik Matice Srpske a Privodne Nauke. 120: 181-194.

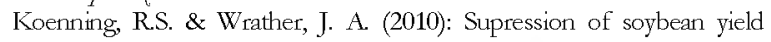
potential in the continental United States by plant diseases from 2006 to 2009. Plant Health Progress, 11(1). do: 10.1094/PHP-2010 1122-01-RS

Lee, J. H., Hwang, S. R, Lee, Y. H., Km, K, Cho, K. M. \& Lee, Y. B. (2015): Changes occurring in compositions and antioxidant properties of healthy soybean seeds [Glyine max (L.) Merr.] and soybean seeds diseased by Phomopsis longicolla and Cerospora kikucbii fungal pathogens. Food Chem. 185: 205-11.

Lević, J., Stanković, S., Krnjaja, V., Bočarov- Stančić, A \& Ivanović, D. (2012): Distribution Frequency and Incidence of Seed-borne Pathogens of Some Cereals and Industrial Crops in Serbia. Pestic. Pbytomed, 27(1): 33-40.

Medić-Pap, S., Milośevic, M. \& Jasnić, S. (2007): Soybean seed-borne fungi in the Vojvodina province. Pbytopathol. Pol, 45: 55-65.

Miladinović, J., Hrustić, M. \& Vidić, M. (2011): Soybean. Novi Sad: Institute of Field and Vegetable Crops.

Oladimeji, A., Olusegun, S. B., Olyemisi, B. F., Oluvatoyin, A. F., Aliye T. H. \& Kassoum O. K. (2016): Seed-borne fungi of soybeans (Glycine max [L.] Merr) in the Guinea Savannah agroecology of Nigeria. Joumal of Agricultural Science, 61: 57-68.

Petrović, K., Riccioni, L., Dorđević, V., Balešević-Tubić, S., Miladinović, J., Ceran, M. \& Rajković, D. (2018). Diaponthe psezdolongicolla: The new pathogen on soybean seed in Serbia. Ratarstwo i Pontarstvo, 55 (2): 103-109.

Petrović, K, Riccioni, L., Vidić, M., Đorđević, V., Balešević-Tubić, S., Đukić, V. \& Miladinov, Z. (2016): First Report of Diaporthe novem, $D$. foenioulina, and $D$. midis Associated With Soybean Seed Decay in Serbia. Plant Disease, 100 (11): 2324.

Petrović, K. \& Vidić, M. (2010): Rasprostranjenost parazita semena soje u Srbiji [Distribution of soybean seed parasites in Serbia]. Zbormik rezimea $X$ Savetovanje o zastiti bilja Book of Abstracts $X$ Counselling of Plant Protection 7, Zlatibor, Srbija, PP. 108-109.

Petrović, K., Vidić, M., Riccioni, L., Đorđević, V. \& Rajković, D. (2015): First Report of Diaporthe eres Species Comples Causing Seed Decay of Soybean in Serbia. Plant Disease, 99 (8): 1186.

Pioli, R. N., Grijalba, P., Gosparini, C. O., Martinez, C., Tozzini, A., Hopp, E. \& Morandi E. N. (1999) Morphological, pathogenic and molecular characterization of different isolates of Diaporthe phaseolonum var. meridionalis obtained in different areas of Santa $\mathrm{Fe}$ province, Argentina. Proc. World Soybean Res. Conf. VI, Chicago. II, USA, PP. 627-628. 
Roy, K. W., Baird, R. E. \& Abney, T. S. (2000): A review of soybean (Glycine max) seed, pod, and flower mycofloras in North America, with methods and a key for identification of selected fungi. Mycopathologia, 150: 15-27.

Rupe, J. C. \& Ferris, R. S. (1986): Effect of pod moisture on soybean seed infection by Phomopsis sp. Pbytopatbology, 76: 273-277.

Sinclair, J. B. \& Backman, P. A. (1989): Compendium of Soybean Diseases ( $3^{\text {rd }}$ Edition). The American Phytopathological Society, St. Paul, Minnesota, USA

Spilker, D. A., Schmitthenner, A. F. \& Ellete, C. W. (1981): Effect of humidity, temperature, fertility and cultivar on the reduction of soybean seed quality by Phomopsis sp. Phytopathology, 71: 10271029 .

Talenko, D. (2018): Indiana Soybeans: Fungal diseases that impact pod, Seed Quality. Purdue University. Retrived from https://agfax.com

Tenuta, A., Bradley, C., Chilver, M., Giesler, L., Mathew, F., Mueller, D., Sisson, A., Smith, D. \& Wise, K. (2015): Scouting for Common Soybean Seed Diseases. Crop Protection Network. Retrieved from http://www.soybeanresearchinfo.com

Vlahović, B., Ilin, S. \& Puškarić, A. (2013): Status and Perspectives of Soybean Production Worldwide and in the Republic of Serbia. Economic Insights - Trends \& Challenges, 65 (1): 38-46.
Vidić, M. (1992): Epidemiološke karakteristike najznačajnijih parazita soje u Vojvodini [Epidemiological characteristics of the most important soybean parasites in Vojvodina]. Zbomik Radova Instituta ₹a Ratarstio i Pourtarstio, 519-522.

Vidić, M., Jasnić, S. \& Đordević, V. (2006): Rasportranjenost Diaponthe/Phomotsis vista na semenu soje u Srbiji Distribution of seed-borne Diaporthe/Phomopsis species in soybean in Serbia]. Pestic. Pbytomed., 21, 39-48.

Vidić, M., Miladinović, J. \& Dordević, V. (2002): Uticaj odlaganja Žetve na intenzitet pojave truleži semena [Effect of harvest delay on the intensity of soya bean seed decay]. Zastita Bitia, 53: 39-50.

Wrather, A. J. \& Kocnning, R. S. (2006): Estimates of disease effects on soybean yields in the United States 2003-2005. Journal of Nematology, 38: 173-180.

Wrather, A. J., Shannon, G., Balardin, R., Carregal, L., Escobar, R., Gupta, G. K., Ma, Z., Morel, W., Ploper, D. \& Tenuta, A. (2010): Effect of diseases on soybean yield in the top eight producing countries in 2006. Plant Health Progress, 11(1). doi: 10.1094/PHP-2010-0125-01-RS.

Xue, A. G., Morrison, M. J., Cober, E., Anderson, T. R., Rioux, S., Ablett, G. R., Rajcan, I., Hall, R. \& Zhang J. X. (2007): Frequency of isolation of species of Diaporthe and Phomopsis from soybean plants in Ontario and benefits of seed treatments. Canadian Journal of Plant Pathology. 29(4): 354-364.

\section{Raznolikost fitopatogenih gljiva na semenu soje u Srbiji}

\section{Slobodan Krsmanović - Kristina Petrović · Marina Ćeran · Vuk Đorđević . Predrag Ranđelović · Simona Jaćimović · Zlatica Miladinov}

Sažetak: Soja je jedna on najznačajnih gajenih industrijskih bilinih vrsta na svetu. Bogat nutritivni sadržaj zrna zaslužan je za sve veću učestalost gajenja ove industrijske biljke širom sveta. Međutim, veliki broj fitopatogenih gliiva egzistira u semenu soje i nepovoljno utiče na hranljivi sadržaj zrna pa samim tim i na smanjenu klijavost i životnu sposobnost. Zdravstveni pregled semena soje u trogodišnjem periodu od 2016. do 2018. godine, pokazao je da fitopatogene vrste iz rodova Alternaria, Diaporthe i Fusarium, kao i vrste Peronospora manshurica, Macrophomina phaseolina, Botrytis cinerea, i Cercospora kikuchii egzistiraju u semenu soje prikupljenom iz sedam lokaliteta u Srbiji. Ipak, $P$. manshurica i vrste iz roda Alternaria pokazale su se kao najdominantnije vrste u sve tri godine. Takođe, ustanovljeno je da vremenski uslovi, lokalitet gajenja i odabir sorte značajno utiču na intenzitet zaraze. Rezultati ovog istraživanja pokazuju koji patogeni predstavljaju pretnju uspešnoj semenskoj proizvodnji soje i pomažu u pronalaženju preventivnih mera za suzbijanje ovih patogena u toku vegetacije. Ključne reči: soja, seme, fitopatogene gljive, učestalost infekcije 